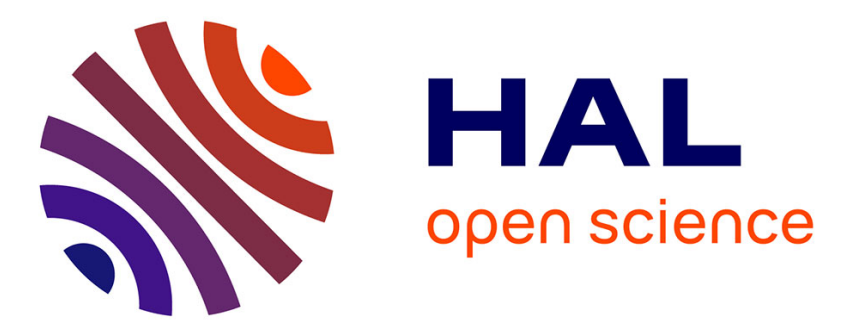

\title{
Low-Temperature Epitaxial Growth Mechanism of Si1-xGex Films in the Silane and Germane Reactions
}

\author{
J. Murota, Y. Takasawa, H. Fujimoto, K. Goto, T. Matsuura, Y. Sawada
}

\section{To cite this version:}

J. Murota, Y. Takasawa, H. Fujimoto, K. Goto, T. Matsuura, et al.. Low-Temperature Epitaxial Growth Mechanism of Si1-xGex Films in the Silane and Germane Reactions. Journal de Physique IV Proceedings, 1995, 05 (C5), pp.C5-1165-C5-1172. 10.1051/jphyscol:19955138 . jpa-00253836

\section{HAL Id: jpa-00253836 https://hal.science/jpa-00253836}

Submitted on 1 Jan 1995

HAL is a multi-disciplinary open access archive for the deposit and dissemination of scientific research documents, whether they are published or not. The documents may come from teaching and research institutions in France or abroad, or from public or private research centers.
L'archive ouverte pluridisciplinaire HAL, est destinée au dépôt et à la diffusion de documents scientifiques de niveau recherche, publiés ou non, émanant des établissements d'enseignement et de recherche français ou étrangers, des laboratoires publics ou privés. 


\title{
Low-Temperature Epitaxial Growth Mechanism of $\mathrm{Si}_{1-x} \mathrm{Ge}_{x}$ Films in the Silane and Germane Reactions
}

\author{
J. Murota, Y. Takasawa(1), H. Fujimoto (2), K. Goto(3), T. Matsuura and Y. Sawada \\ Laboratory for Electronic Intelligent Systems, Research Institute of Electrical Communication, Tohoku \\ University, 2-1-1 Katahira, Aoba-ku, Sendai 980-77, Japan
}

\begin{abstract}
Low-temperature epitaxial growth of undoped and doped $\mathrm{Si}_{1-x} \mathrm{Ge}_{\mathrm{x}}$ films on the $\mathrm{Si}(100)$ surface at $550^{\circ} \mathrm{C}$ was investigated under the cleanest possible reaction environment of $\mathrm{SiH}_{4}, \mathrm{GeH}_{4}$ and $\mathrm{H}_{2}$ with the $\mathrm{PH}_{3}$ or $\mathrm{B}_{2} \mathrm{H}_{6}$ addition using an ultraclean hot-wall low-pressure chemical vapour deposition (LPCVD) system. The $\mathrm{SiH}_{4}$ and $\mathrm{GeH}_{4}$ reaction rates are expressed by the Langmuir-type rate equation, assuming that one $\mathrm{SiH}_{4}$ or $\mathrm{GeH}_{4} \mathrm{molecule}$ is adsorbed at a single adsorption site, according to the Langmuir's adsorption isotherm, and decomposes there. It is found that the $\mathrm{SiH}_{4}$ and $\mathrm{GeH}_{4}$ adsorption rate constants become larger at the bond site of the $\mathrm{Si}-\mathrm{Ge}$ pair than those at the others, while the $\mathrm{SiH}_{4}$ surface reaction rate constant becomes the largest at the bond site of the Ge-Ge pair. With the $\mathrm{PH}_{3}$ and $\mathrm{B}_{2} \mathrm{H}_{6}$ addition, the incorporation rate of $\mathrm{P}$ and $\mathrm{B}$ increased proportionally and was higher with a higher Ge fraction $\mathrm{x}$ in the film. This was explained by the increase of the free site density and the difference of free site materials according to the Langmuir-type rate equation. In the case of $P$ doping, it is found that electrically inactive $\mathbf{P}$ is formed with high $\mathrm{Ge}$ fractions.
\end{abstract}

\section{INTRODUCTION}

The growth of $\mathrm{Si} / \mathrm{Si}_{1-\mathrm{x}} \mathrm{Ge}_{\mathrm{x}} / \mathrm{Si}$ heterostructure at low-temperatures has attracted interest for the fabrication of novel heterostructure devices [1-3]. Low-temperature LPCVD allows to control film thickness and doping concentration, e.g. abrupt steps in the doping profile, that is a key point for realizing the devices with high performance. Recently, improvements in the quality of gases and CVD equipments have enabled low-temperature epitaxial growth processing [4-7]. For excellent heterodevices, high Ge fractions in the strained $\mathrm{Si}_{1-\mathrm{x}} \mathrm{Ge}_{\mathrm{x}}$ layer are necessary. However, the deposition mechanism and in-situ doping only for $\mathrm{Si}_{1-\mathrm{x}} \mathrm{Ge}_{\mathrm{x}}$ layers with $\mathrm{x}$ around 0.25 or less, deposited at a temperature above $600^{\circ} \mathrm{C}$, were reported by many researchers [8-11]. At a higher Ge fraction, heterojunction appears to be degraded by island growth as well as by generation of misfit dislocations due to the larger mismatch between the $\mathrm{Si}$ and $\mathrm{Si}_{1-\mathrm{x}} \mathrm{Ge}_{\mathrm{x}}$ layers [12]. In the previous work, the epitaxial growth process of the $\mathrm{Si} / \mathrm{Si}_{1-\mathrm{x}} \mathrm{Ge}_{\mathrm{x}} / \mathrm{Si}$ heterostructure at a temperature below $600^{\circ} \mathrm{C}$ is optimized in order to obtain atomically flat surfaces and interfaces at high Ge fractions [13-15].

In the present paper, we describe low-temperature epitaxial growth of $\mathrm{Si}_{1-\mathrm{x}} \mathrm{Ge}_{\mathrm{x}}$ films on $\mathrm{Si}$ using $\mathrm{SiH}_{4}$, $\mathrm{GeH}_{4}$ and $\mathrm{H}_{2}$ gas mixture as well as in-situ doping using $\mathrm{PH}_{3}$ and $\mathrm{B}_{2} \mathrm{H}_{6}$ by the ultraclean LPCVD at a deposition temperature of $550^{\circ} \mathrm{C}$. Control of the deposition rate and Ge fraction in the grown film and in-situ doping of $\mathrm{P}$ and $\mathrm{B}$ are discussed based on the Langmuir adsorption-type model.

(1) On leave from Kokusai Electric Co., Ltd., Toyama Works, 2-1 Yasuuchi, Yatsuomachi, Neigun, Toyama 939-23, Japan

(2) On leave from Miyagi OKI Electric Co., Ltd., 1 Okinodaira, Ohiramura, Kurokawagun, Miyagi 98136, Japan

(3) DC Research Fellow of the Japan Society for the Promotion of Science

Article published online by EDP Sciences and available at http://dx.doi.org/10.1051/jphyscol:19955138 


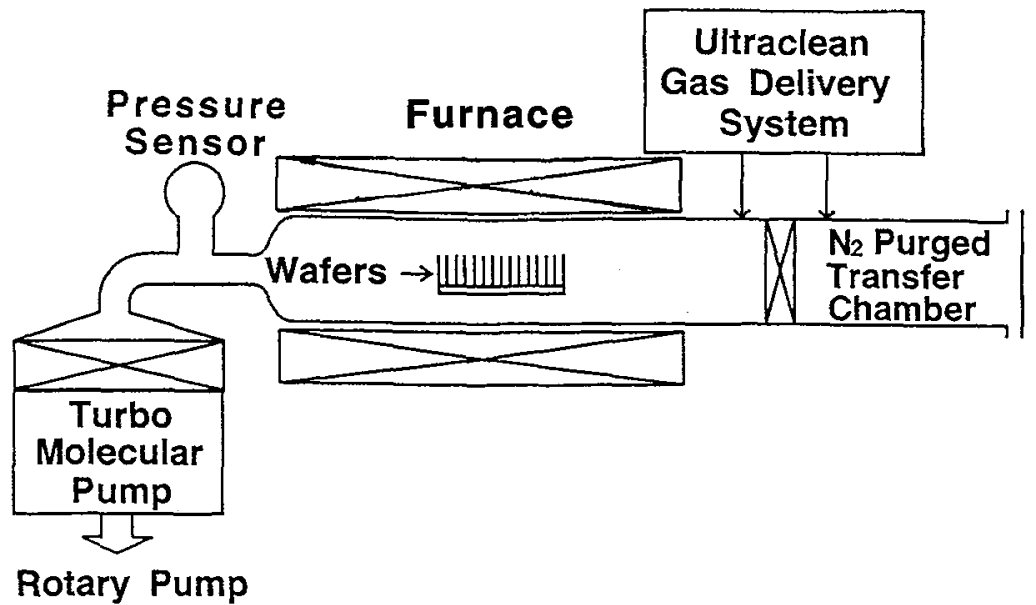

Figure 1: Schematic diagram of an ultraclean hot-wall LPCVD system.

\section{EXPERIMENTAL}

The $\mathrm{Si}_{1-\mathrm{x}} \mathrm{Ge}_{\mathrm{x}}$ films were epitaxially grown on $\mathrm{Si}(100)$ surface at $550^{\circ} \mathrm{C}$ in a $\mathrm{SiH}_{4}-\mathrm{GeH}_{4}-\mathrm{H}_{2}$ gas mixture using an ultraclean hot-wall LPCVD system, schematically shown in Figure 1 [6]. The LPCVD system was made ultrahigh vacuum compatible with gate valves and a turbo molecular pump system. The turbo molecular pump system was improved to vacuum-evacuate from atmospheric pressure. To minimize air-contamination in the reactor during the wafer load and unload, a $\mathrm{N}_{2}$ purged transfer chamber was combined with the reactor inlet. The optimized deposition process sequence for high quality $\mathrm{Si}_{1-\mathrm{x}} \mathrm{Ge}_{\mathrm{x}}$ heteroepitaxial growth on $\mathrm{Si}$ using this system have been described in detail elsewhere $[7,14,15]$. The in-situ doping was performed by introducing $\mathrm{B}_{2} \mathrm{H}_{6}$ and $\mathrm{PH}_{3}$ gases. The total deposition pressure was about $30 \mathrm{~Pa}$, and the partial pressures of $\mathrm{SiH}_{4}, \mathrm{GeH}_{4}$ and $\operatorname{dopant}\left(\mathrm{PH}_{3}\right.$ or $\left.\mathrm{B}_{2} \mathrm{H}_{6}\right)$ were in the range $0.26-10.6,0-6.0,1.25 \times 10^{-5}-1.25 \times 10^{-3} \mathrm{~Pa}$, respectively. The film thicknesses ranged from 14 to $500 \mathrm{~nm}$. As substrates for undoping and $\mathrm{P}$ doping, $\mathrm{p}$-type Si wafers of 2-20 ohm-cm with mirror polished (100) surfaces were used, and for $B$ doping, n-type wafers of 3-5 ohm-cm. Before loading the wafers into the transfer chamber, they were cleaned in several cycles in a $4: 1$ solution of $\mathrm{H}_{2} \mathrm{SO}_{4}$ and $\mathrm{H}_{2} \mathrm{O}_{2}$, high-purity DI water, and $1-2 \%$ HF with the final rinse in DI water.

The Ge fraction $\mathrm{x}$ was estimated from the lattice constant measured by $\mathrm{x}$-ray diffraction. The $\mathrm{P}$ and $\mathrm{B}$ concentration in $\mathrm{Si}_{1-\mathrm{x}} \mathrm{Ge}_{\mathrm{x}}$ films was determined by secondary ion mass spectroscopy. The film thickness was measured by using a step profiler. To measure the carrier concentration in $\mathrm{Si}_{1-\mathrm{x}} \mathrm{Ge}_{\mathrm{x}}$ films, a clover-leaf area of $\mathrm{Si}_{1-\mathrm{x}} \mathrm{Ge}_{\mathrm{x}}$ film on $\mathrm{Si}$ substrate was defined by photolithography and chemical etch, and the sheet resistivity and the Hall coefficient were measured by the van der Pauw method at room temperature.

\section{CONTROL OF DEPOSITION RATE AND GERMANIUM FRACTION}

The respective reaction rates of $\mathrm{GeH}_{4}$ and $\mathrm{SiH}_{4}$ are obtained as the products of deposition rate with $\mathrm{Ge}$ fraction and Si fraction, respectively. These results are shown in Figures 2 [15] and 3. With increasing $\mathrm{GeH}_{4}$ partial pressure, the $\mathrm{GeH}_{4}$ reaction rate increases monotonically while the $\mathrm{SiH}_{4}$ reaction rate increases up to the maximum value and then decreases. With increasing $\mathrm{SiH}_{4}$ partial pressure, the $\mathrm{GeH}_{4}$ 


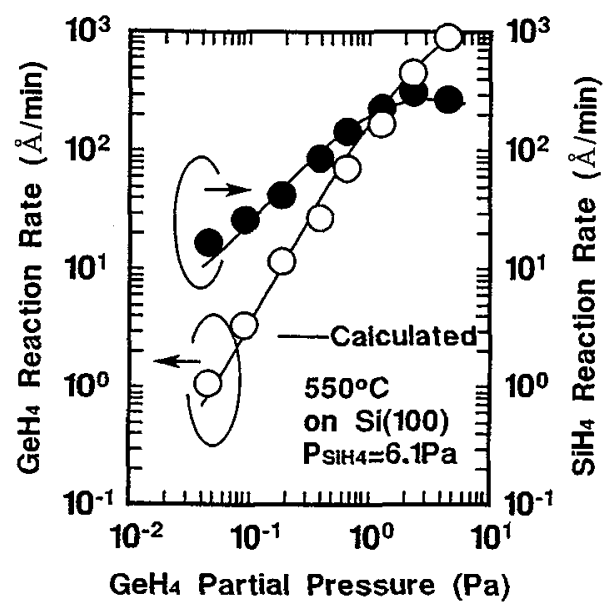

Figure 2: $\mathrm{GcH}_{4}$ partial pressure dependence of the $\mathrm{GeH}_{4}$ and $\mathrm{SiH}_{4}$ reaction rates in the $\mathrm{Si}_{1-\mathrm{x}} \mathrm{Ge}_{\mathrm{x}}$ deposition. The $\mathrm{SiH}_{4}$ partial pressure is $6.1 \mathrm{~Pa}$ and the $\mathrm{H}_{2}$ partial pressure $25 \mathrm{~Pa}$. The solid lines are calculated from equations (3)-(6) using the parameters in Table I.

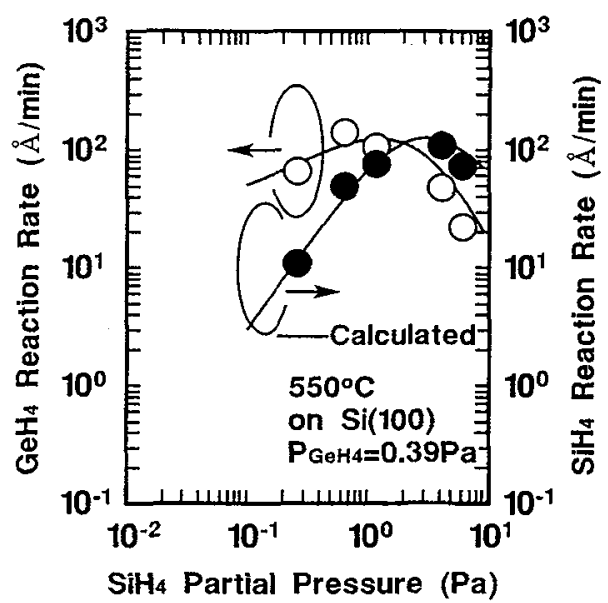

Figure 3: $\mathrm{SiH}_{4}$ partial pressure dependence of the $\mathrm{GcH}_{4}$ and $\mathrm{SiH}_{4}$ reaction rates in the $\mathrm{Si}_{1-\mathrm{x}} \mathrm{Ge}_{\mathrm{x}}$ deposition. The $\mathrm{GeH}_{4}$ partial pressure is $0.39 \mathrm{~Pa}$ and the $\mathrm{H}_{2}$ partial pressure $25 \mathrm{~Pa}$. The solid lines are calculated from equations (3)-(6) using the parameters in Table I.

and $\mathrm{SiH}_{4}$ reaction rates increase up to the maximum value and then decrease. Since these thicknesses and Ge fractions had uniformities better than $5 \%$ within a wafer and from wafer to wafer for 1.25 -inch-diam wafers set as shown in Figure 1, and scarcely depended on the wafer spacing in the range 6-20mm and the gas flow rate, the reaction rate was confirmed to be controlled by the surface reaction.

Now, assuming that one $\mathrm{SiH}_{4}$ or $\mathrm{GeH}_{4}$ molecule is adsorbed at a single adsorption site, according to the Langmuir's adsorption isotherm, and decomposes there [16,17], the $\mathrm{SiH}_{4}$ and $\mathrm{GeH}_{4}$ reaction rates $\mathrm{R}_{\mathrm{Si}}$ and $\mathrm{R}_{\mathrm{Ge}}$ are given by

$$
\begin{aligned}
& \mathrm{R}_{\mathrm{Si}}=\frac{\mathrm{k}_{\mathrm{Si}}\left[\mathrm{k}_{1} /\left(\mathrm{k}_{\mathrm{Si}}+\mathrm{k}_{-1}\right)\right] \mathrm{P}_{\mathrm{SiH} 4} \mathrm{n}_{\mathrm{o}}}{1+\left[\mathrm{k}_{1} /\left(\mathrm{k}_{\mathrm{Si}}+\mathrm{k}_{-1}\right)\right] \mathrm{P}_{\mathrm{SiH} 4}+\left[\mathrm{k}_{2} /\left(\mathrm{k}_{\mathrm{Ge}}+\mathrm{k}_{-2}\right)\right] \mathrm{P}_{\mathrm{GeH} 4}}, \\
& \mathrm{R}_{\mathrm{Ge}}=\frac{\mathrm{k}_{\mathrm{Ge}}\left[\mathrm{k}_{2} /\left(\mathrm{k}_{\mathrm{Ge}}+\mathrm{k}_{-2}\right)\right] \mathrm{P}_{\mathrm{GeH} 4} \mathrm{n}_{\mathrm{o}}}{1+\left[\mathrm{k}_{1} /\left(\mathrm{k}_{\mathrm{Si}}+\mathrm{k}_{-1}\right)\right] \mathrm{P}_{\mathrm{SiH} 4}+\left[\mathrm{k}_{2} /\left(\mathrm{k}_{\mathrm{Ge}}+\mathrm{k}_{-2}\right)\right] \mathrm{P}_{\mathrm{GeH} 4}},
\end{aligned}
$$

where $\mathrm{k}_{\mathrm{Si}}$ and $\mathrm{k}_{\mathrm{Ge}}$ are the $\mathrm{SiH}_{4}$ and $\mathrm{GeH}_{4}$ reaction rate constants, $\mathrm{k}_{1}$ and $\mathrm{k}_{2}$ the $\mathrm{SiH}_{4}$ and $\mathrm{GeH}_{4}$ adsorption rate constants, and $\mathrm{k}_{-1}$ and $\mathrm{k}_{-2}$ the $\mathrm{SiH}_{4}$ and $\mathrm{GeH}_{4}$ desorption rate constants, respectively. The expressions of $\mathrm{k}_{1} /\left(\mathrm{k}_{\mathrm{Si}}+\mathrm{k}_{-1}\right)$ and $\mathrm{k}_{2} /\left(\mathrm{k}_{\mathrm{Ge}}+\mathrm{k}_{-2}\right)$ denote the $\mathrm{SiH}_{4}$ and $\mathrm{GeH}_{4}$ adsorption equilibrium constants, $n_{0}$ is the total adsorption site density, and $\mathrm{P}_{\mathrm{SiH} 4}$ and $\mathrm{P}_{\mathrm{GeH} 4}$ are the $\mathrm{SiH}_{4}$ and $\mathrm{GeH}_{4}$ partial pressures, respectively. Since the $\mathrm{GeH}_{4}$ reaction rate in pure Ge deposition was nearly proportional to the $\mathrm{GeH}_{4}$ partial pressure while the $\mathrm{SiH}_{4}$ reaction rate in pure Si deposition was not strongly dependent on the $\mathrm{SiH}_{4}$ partial pressure under similar deposition conditions as that of Figure 3, it is expected that $\left[\mathrm{k}_{1} /\left(\mathrm{k}_{\mathrm{Si}}+\mathrm{k}_{-1}\right)\right] \mathrm{P}_{\mathrm{SiH} 4} \gg\left[\mathrm{k}_{2} /\left(\mathrm{k}_{\mathrm{Ge}}+\mathrm{k}_{-2}\right)\right] \mathrm{P}_{\mathrm{GeH} 4}$ in equations (1) and (2); in other words, the density of adsorbed $\mathrm{Ge}$ hydrides is negligibly small compared with the total adsorption site density, but that of $\mathrm{Si}$ hydrides cannot be neglected under the investigated conditions [7]. Assuming $\mathrm{k}_{\mathrm{Si}}>>\mathrm{k}_{-1}$ and $\mathrm{k}_{\mathrm{Ge}}>>\mathrm{k}_{-2}$, equations (1) and (2) become 


$$
\begin{aligned}
& R_{\mathrm{Si}}=\frac{\mathrm{k}_{1} \mathrm{P}_{\mathrm{SiH}_{4} \mathrm{n}_{\mathrm{o}}}}{1+\left(\mathrm{k}_{1} / \mathrm{k}_{\mathrm{Si}}\right) \mathrm{P}_{\mathrm{SiH} 4}}, \\
& \mathrm{R}_{\mathrm{Ge}}=\frac{\mathrm{k}_{2} \mathrm{P}_{\mathrm{GeH} 4} \mathrm{n}_{\mathrm{o}}}{1+\left(\mathrm{k}_{1} / \mathrm{k}_{\mathrm{Si}}\right) \mathrm{P}_{\mathrm{SiH} 4}} .
\end{aligned}
$$

The Ge fraction $x$ is given by

$$
x=\frac{R_{G e}}{R_{S i}+R_{G e}}=\frac{k_{2}}{k_{1}} \cdot \frac{P_{G e H 4}}{P_{S_{H} 4}+\left(k_{2} / k_{1}\right) P_{G e H 4}}
$$

As shown in Figure 2, the $\mathrm{SiH}_{4}$ reaction rate is enhanced with $\mathrm{GeH}_{4}$ addition, and the $\mathrm{GeH}_{4}$ reaction rate for $\mathrm{GeH}_{4}$ partial pressure has a slope greater than 1, and as shown in Figure 3, the $\mathrm{GeH}_{4}$ reaction rate is also enhanced up to a certain value with $\mathrm{SiH}_{4}$ addition. These results mean that $\mathrm{k}_{\mathrm{Si}}, \mathrm{k}_{1}$ and $\mathrm{k}_{2}$ included in equations (3) and (4) depend on the $\mathrm{Si}$ and Ge bond structures at the adsorption site, although the adsorption forms of $\mathrm{Si}$ and $\mathrm{Ge}$ hydrides are not clear at present. In the case of the reaction on the (100) surface, there are three kinds of opposite bonds, namely, the $\mathrm{Si}-\mathrm{Si}, \mathrm{Si}-\mathrm{Ge}$, and $\mathrm{Ge}-\mathrm{Ge}$ pairs whose densities are proportional to $n_{0}(1-x)^{2}, 2 n_{0} x(1-x)$ and $n_{0} x^{2}$, respectively. Then, $k_{a} n_{0}(a=1,2$, Si) can be expressed as

$k_{a} n_{0}=k_{a 1} n_{o}(1-x)^{2}+2 k_{a 2} n_{o} x(1-x)+k_{a 3} n_{o} x^{2}$

where $\mathrm{k}_{\mathrm{a} 1}, \mathrm{k}_{\mathrm{a} 2}$ and $\mathrm{k}_{\mathrm{a} 3}$ are the rate constants at the Si-Si pair, Si-Ge pair and Ge-Ge pair, respectively, on the (100) surface. The values of $\mathrm{k}_{\mathrm{ab}} \mathrm{n}_{\mathrm{o}}(\mathrm{a}=1,2, \mathrm{Si} ; \mathrm{b}=1,2,3)$ are determined so that equations (3)-(6) can fit the data shown in Figures 2 and 3. The values of $k_{11} n_{0}$ and $k_{S i 1} n_{o}$ are estimated from the pure $\mathrm{Si}$ deposition rate, and that of $\mathrm{k}_{23} \mathrm{n}_{\mathrm{o}}$ is from the pure Ge deposition rate. Also, it is assumed that the values of $k_{22} / k_{12}$ and $k_{23} / k_{13}$ are equal to the $k_{2} / k_{1}$ values calculated from equation (5) using experimental data at higher $\mathrm{GeH}_{4}$ partial pressures, and the values of $\mathrm{k}_{21} / \mathrm{k}_{11}$ is equal to $\mathrm{k}_{2} / \mathrm{k}_{1}$ values at lower $\mathrm{GeH}_{4}$ partial pressures. Based on the estimations and the assumptions, the values of $k_{12} n_{0}$ or $k_{22} n_{0}$, $\mathrm{k}_{\mathrm{Si2}} \mathrm{n}_{\mathrm{o}}$ and $\mathrm{k}_{\mathrm{Si} 3} \mathrm{n}_{\mathrm{o}}$ are obtained numerically by fitting the data shown in Figure 2 to equations (3)-(6). These values are shown in Table I. Very good agreement is obtained between the reaction rate (solid lines in Figures 2 and 3) calculated from equations (3)-(6) with the values shown in Table I, and the experimental data. $A \sim 20 \%$ shift of the calculated reaction rate is induced by $20 \%$ deviations from the values of both $\mathrm{k}_{12} \mathrm{n}_{\mathrm{o}}$ and $\mathrm{k}_{22} \mathrm{n}_{\mathrm{o}}$, and/or $\mathrm{k}_{S \mathrm{i} 3} \mathrm{n}_{\mathrm{o}}$ shown in Table $\mathrm{I}$, but there is little shift even for a 100\% deviation of $\mathrm{k}_{\mathrm{Si} 2} \mathrm{n}_{\mathrm{o}}$. From Table $\mathrm{I}$ in such accuracy, it is found that the $\mathrm{SiH}_{4}$ and $\mathrm{GeH}_{4}$ adsorption rate constants become larger at the bond site of the Si-Ge pair than those at the bond sites of the others, while the $\mathrm{SiH}_{4}$ surface reaction rate constant becomes the largest at the bond site of the Ge-Ge pair. The enhancement of the $\mathrm{SiH}_{4}$ reaction rate constant at the bond site of $\mathrm{Ge}$ may result from $\mathrm{Ge}$ acting as a desorption center for hydrogen atoms of $\mathrm{SiH}_{4}$ on the surface [5].

Table I: The fitting parameters $k_{1 b} n_{0}, k_{2 b} n_{0}$ and $k_{S i b} n_{o}$ on the (100) surface, calculated from equations (3)-(6) using data of Figure 2.

\begin{tabular}{cccc}
\hline $\mathrm{b}$ & $\mathrm{k}_{1 \mathrm{~b}} \mathrm{n}_{\mathrm{o}}\left(\AA \min ^{-1} \mathrm{~Pa}^{-1}\right)$ & $\mathrm{k}_{2 \mathrm{~b}} \mathrm{n}_{\mathrm{o}}\left(\AA \min ^{-1} \mathrm{~Pa}^{-1}\right)$ & $\mathrm{k}_{\mathrm{Sib}_{\mathrm{o}} \mathrm{n}_{\mathrm{o}}\left(\AA \min ^{-1}\right)}$ \\
\hline 1 & 28 & 390 & 5 \\
2 & 140 & 600 & 5 \\
3 & 17 & 75 & 1500 \\
\hline
\end{tabular}


In the case of the present pure $\mathrm{Si}$ deposition without $\mathrm{GeH}_{4}$, the activation energy of the $\mathrm{SiH}_{4}$ reaction rate constant was about $41 \mathrm{kcal} / \mathrm{mol}$, which was in good agreement with that of the deposition rate under the investigated pressure conditions, and also with that in other investigations $[16,18]$. It has been reported that the $\mathrm{Si}$ deposition is limited by $\mathrm{SiH}$ decomposition, in other words, hydrogen desorption from $\mathrm{SiH}[19,20]$. It is found that the $\mathrm{SiH}_{4}$ reaction rate constant, $\mathrm{k}_{\mathrm{Si} 1} \mathrm{n}_{\mathrm{o}}$ listed in Table I, agrees with the $\mathrm{SiH}$ one estimated from ref.21 within 50\%. Also the equilibrium surface $\mathrm{SiH}_{4}$ coverage, $\left(\mathrm{k}_{11} / \mathrm{k}_{\mathrm{Si} 1}\right) \mathrm{P}_{\mathrm{SiH} 4} /[1+$ $\left.\left(\mathrm{k}_{11} / \mathrm{k}_{\mathrm{Sil}}\right) \mathrm{P}_{\mathrm{SiH} 4}\right]$, during pure Si deposition calculated from Table $\mathrm{I}$ is in good agreement with the data of equilibrium surface hydrogen coverage in ref.18. Therefore, it is suggested that $\mathrm{k}_{\mathrm{Sil}} \mathrm{n}_{\mathrm{o}}$ is the SiH decomposition rate constant and $k_{11} n_{0}$ is the total $\mathrm{SiH}$ formation rate constant at the surface from $\mathrm{SiH}_{4}$ in the gas phase. For the case of $\mathrm{GeH}_{4}$ decomposition, it has been reported that $\mathrm{Si}$ atoms play the role of decomposition centers of $\mathrm{GeH}_{4}$ with $\mathrm{SiH}$ formation, even though the decomposition rate of $\mathrm{GeH}_{4}$ is larger at the $\mathrm{Ge}$ bond sites than at the $\mathrm{Si}$ bond sites, and $\mathrm{SiH}$ decomposition is enhanced by the existence of $\mathrm{Ge}$ atoms on $\mathrm{Si}(100)$ [22]. Based on this reported result, it is considered for values in Table I that the $\mathrm{SiH}_{4}$ reaction rate constant becomes large at the bond site of $\mathrm{Ge}$, and $\mathrm{SiH}_{4}$ adsorption rate constant $\mathrm{k}_{12} \mathrm{n}_{0}$, in other words, the $\mathrm{SiH}$ formation rate constant, is enlarged through $\mathrm{SiH}$ generation from $\mathrm{GeH}_{4}$ decomposition, and the $\mathrm{GeH}_{4}$ adsorption rate constants $\mathrm{k}_{21} \mathrm{n}_{\mathrm{o}}$ and $\mathrm{k}_{22} \mathrm{n}_{0}$, in other words, GeH formation rate constants include the transition to $\mathrm{GeH}$ due to $\mathrm{SiH}$ generation from $\mathrm{GeH}_{4}$ in the gas phase. Further investigations on such decomposition steps are necessary.

\section{IN-SITU DOPING OF P AND B}

Figure 4 shows the dependence of the carrier concentration in $\mathrm{Si}_{1-\mathrm{x}} \mathrm{Ge}_{\mathrm{x}}$ films on the $\mathrm{PH}_{3}$ partial pressure. The carrier concentration is linear with the $\mathrm{PH}_{3}$ partial pressure. The deposition rate becomes to be independent of the $\mathrm{PH}_{3}$ partial pressure with increasing Ge fraction as shown in Figure 5 and the Ge fraction $\mathrm{x}$ of $\mathrm{Si}_{1-\mathrm{x}} \mathrm{Ge}_{\mathrm{x}}$ films scarcely depends on the $\mathrm{PH}_{3}$ partial pressure as shown in Figure 6. From Figures 5 and 6, the dependence of the carrier incorporation rate, given by the product of the carrier concentration and the deposition rate on the $\mathrm{PH}_{3}$ partial pressure is obtained as shown in Figure 7. The carrier incorporation rate is linear with the $\mathrm{PH}_{3}$ partial pressure. A similar relationship was obtained for $B$ doping by introducing $\mathrm{B}_{2} \mathrm{H}_{6}$ [23]. Figure 8 shows the Ge fraction dependence of the impurity and carrier incorporation rates normalized by the dopant partial pressure. The normalized incorporation rates

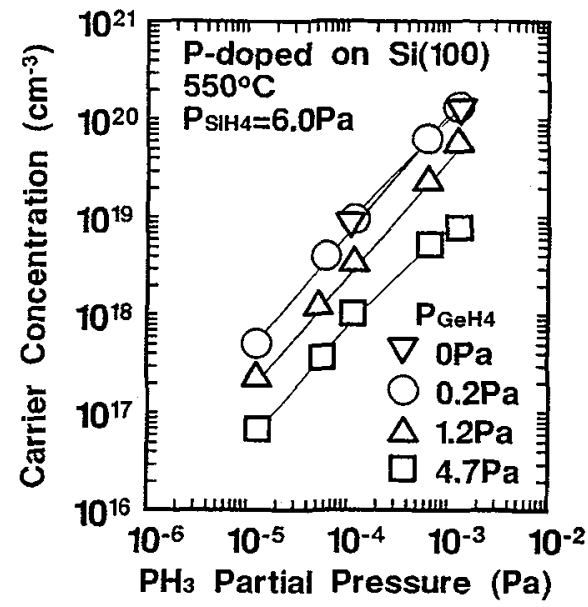

Figure 4: $\mathrm{PH}_{3}$ partial pressure dependence of the carrier concentration in $\mathrm{Si}_{1-\mathrm{x}} \mathrm{Ge}_{\mathrm{x}}$ films.

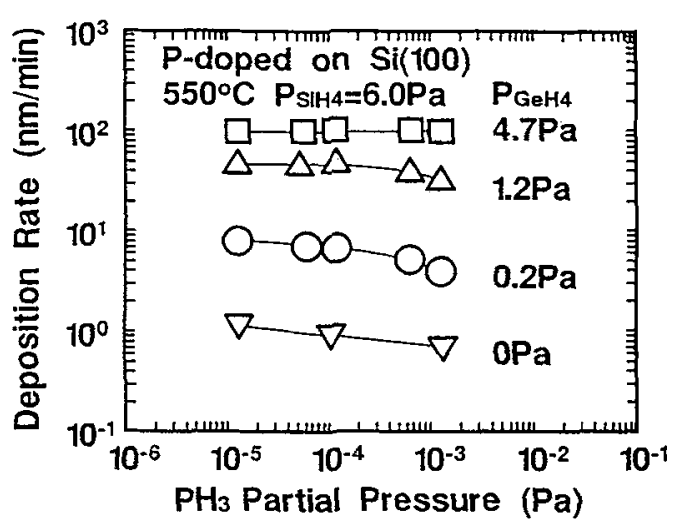

Figure 5: $\mathrm{PH}_{3}$ partial pressure dependence of the deposition rate of $\mathrm{Si}_{1-\mathrm{x}} \mathrm{Ge}_{\mathbf{x}}$ films. 


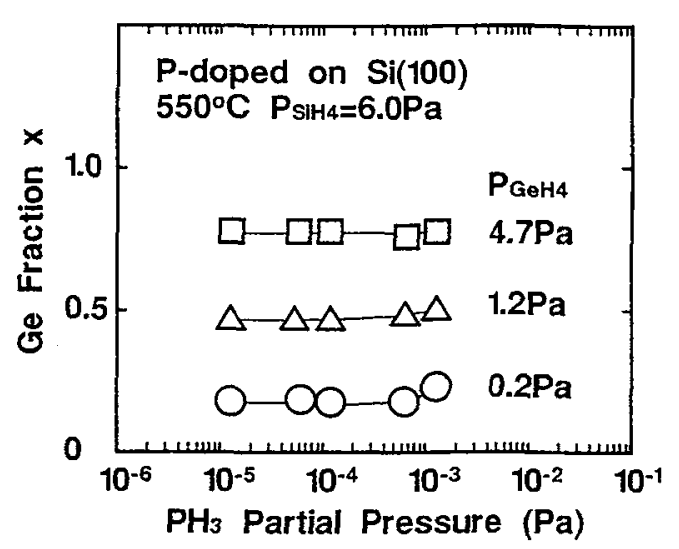

Figure 6: $\mathrm{PH}_{3}$ partial pressure dependence of the $\mathrm{Ge}$ fraction in $\mathrm{Si}_{1-\mathrm{x}} \mathrm{Ge}_{\mathrm{x}}$ films.

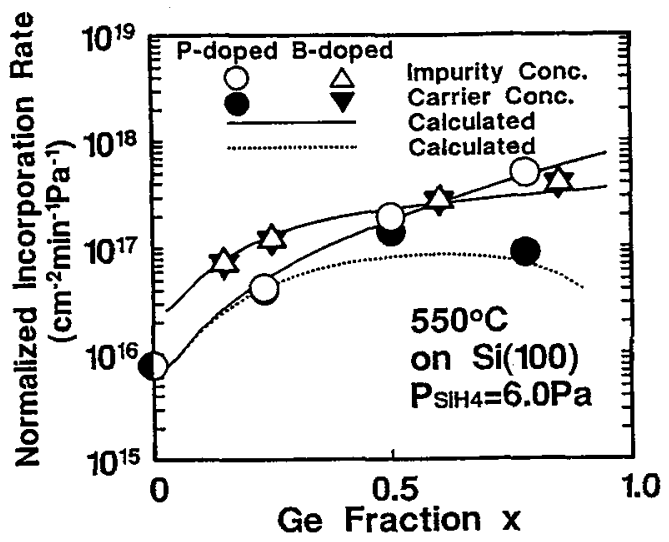

Figure 8: Ge fraction dependence of the impurity and carrier incorporation rates on the (100) surface, normalized by dopant partial pressure, at $550^{\circ} \mathrm{C}$. The solid lines for impurity and the dotted line for carrier are calculated from equations (6)(8) with the parameters in Table I and II.

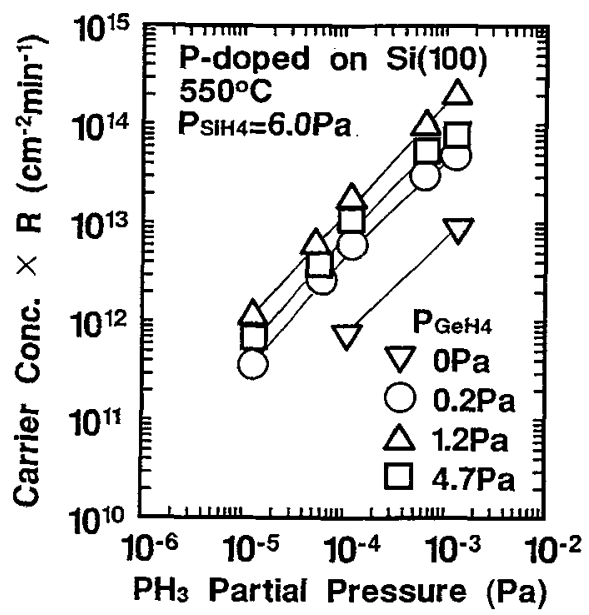

Figure 7: $\mathrm{PH}_{3}$ partial pressure dependence of the carrier incorporation rate.

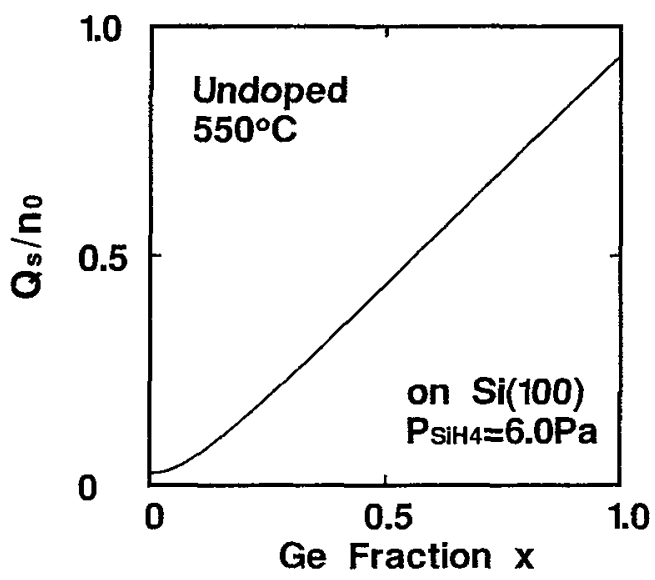

Figure 9: Ge fraction dependence of $Q_{s}$ on the (100) surface at a $\mathrm{SiH}_{4}$ partial pressure of $6.0 \mathrm{~Pa}$ at $550^{\circ} \mathrm{C}$, calculated from equations (6) and (7) using the fitting parameters in Table I.

of $P$ and $B$ increase [23] with increasing Ge fraction. Therefore, it is suggested that the incorporation of $P$ and $B$ into $\mathrm{Si}_{1-x} \mathrm{Ge}_{\mathbf{x}}$ films is not limited by the mass-transport of dopant in the gas phase, but is controlled by the surface reactions in the investigated conditions. In the case of $\mathrm{P}$ doping, it is found that electrically inactive P is formed with high Ge fractions. Since it was reported [24] that the electrically inactive $P$ atoms exist in bulk Ge even in the lower concentration below $10^{20} \mathrm{~cm}^{-3}$, that is not observed in bulk $\mathrm{Si}$, it is considered that $\mathrm{P}$ bonded to $\mathrm{Ge}$ atoms tends to be electrically inactive.

Now, assuming that one $\mathrm{PH}_{3}$ or $\mathrm{BH}_{3}$ molecule is adsorbed at one free surface site which is not occupied by $\mathrm{Si}$-hydride or $\mathrm{Ge}$-hydride, and decomposes there, the $\mathrm{P}$ or $\mathrm{B}$ incorporation rate $\mathrm{R}_{\mathrm{I}}$ is given by 
$R_{\mathrm{I}}=\mathrm{k}_{\mathrm{I}} \mathrm{P}_{\mathrm{I}} \mathrm{Q}_{\mathrm{s}}=\frac{\mathrm{k}_{\mathrm{I}} \mathrm{P}_{\mathrm{I}} \mathrm{n}_{\mathrm{o}}}{1+\left(\mathrm{k}_{1} / \mathrm{k}_{\mathrm{Si}}\right) \mathrm{P}_{\mathrm{SiH} 4}}$,

where $\mathrm{k}_{\mathrm{I}}$ is the incorporation rate constant of $\mathrm{PH}_{3}$ or $\mathrm{B}_{2} \mathrm{H}_{6}, \mathrm{P}_{\mathrm{I}}$ the $\mathrm{PH}_{3}$ or $\mathrm{B}_{2} \mathrm{H}_{6}$ partial pressure, $\mathrm{Q}_{\mathrm{s}}$ the free surface site density. It is also assumed that $\mathrm{B}_{2} \mathrm{H}_{6}$ molecules are decomposed completely into $\mathrm{BH}_{3}$ in the gas phase [25]. $Q_{s}$ is calculated from equations (6) and (7) using the fitting parameters in Table I neglecting dopant adsorption because the deposition rate scarcely depended on the dopant partial pressure in the investigated conditions. Then, $Q_{s}$ increases with increasing Ge fraction as shown in Figure 9. Substituting the values shown in Figures 8 and 9 into equation (7), it is found that the increase of the impurity incorporation rate with increasing Ge fraction is caused mainly by the increase of $Q_{s}$ and $k_{I}$ for $\mathrm{PH}_{3}$ increases with $\mathrm{Ge}$ fraction, but that for $\mathrm{B}_{2} \mathrm{H}_{6}$ decreases. Therefore, it is suggested that $\mathrm{k}_{1}$ depends on the $\mathrm{Si}$ and $\mathrm{Ge}$ bond structure at the adsorption site. Then, $\mathrm{k}_{\mathrm{I}} \mathrm{n}_{\mathrm{o}}\left(\mathrm{I}=\mathrm{PH}_{3}\right.$ or $\left.\mathrm{B}_{2} \mathrm{H}_{6}\right)$ for the (100) surface can be given by the similar form as equation (6),

$k_{I} n_{0}=k_{I 1} n_{0}(1-x)^{2}+2 k_{I 2} n_{0} x(1-x)+k_{I 3} n_{0} x^{2}$

The values of $\mathrm{k}_{\mathrm{I} 1}, \mathrm{k}_{\mathrm{I} 2}$ and $\mathrm{k}_{\mathrm{I} 3}$ which are the incorporation rate constants at the Si-Si pair, Si-Ge pair and $\mathrm{Ge}-\mathrm{Ge}$ pair, respectively, are obtained by fitting the data shown in Figure 8 to equations (6)-(8) with the value shown in Table I. These values are shown in Table II. Very good agreement is obtained between the normalized incorporation rate of impurity(solid lines in Figure 8) calculated from equations (6)-(8) with the values shown in Tables I and II, and the experimental data. From Table II, it is found that the $\mathrm{P}$ incorporation rate constant becomes the largest at the $\mathrm{Ge}-\mathrm{Ge}$ pair, but the $\mathrm{B}$ incorporation rate at the $\mathrm{Si}-\mathrm{Si}$ pair. Assuming that $\mathrm{P}$ incorporated at the $\mathrm{Ge}-\mathrm{Ge}$ pair is electrically inactive, the calculated carrier incorporation rate (dotted line in Figure 8) agrees with the experimental data. Further investigation on such electrical inactivity of impurity in $\mathrm{Si}_{1-\mathrm{x}} \mathrm{Ge}_{\mathbf{x}}$ films are necessary.

Table II: The fitting parameters $\mathrm{k}_{\mathrm{Pb}} \mathrm{n}_{\mathrm{o}}$ and $\mathrm{k}_{\mathrm{Bb}} \mathrm{n}_{\mathrm{o}}$ on the (100) surface at $550^{\circ} \mathrm{C}$, calculated from equations (6)-(8) and Table I using data of Figure 8.

\begin{tabular}{ccc}
\hline $\mathrm{b}$ & $\mathrm{k}_{\mathrm{Pb}} \mathrm{n}_{\mathrm{o}}\left(\mathrm{cm}^{-2} \min ^{-1} \mathrm{~Pa}^{-1}\right)$ & $\mathrm{k}_{\mathrm{Bb}} \mathrm{n}_{\mathrm{o}}\left(\mathrm{cm}^{-2} \min ^{-1} \mathrm{~Pa}^{-1}\right)$ \\
\hline 1 & $2.5 \times 10^{17}$ & $9 \times 10^{17}$ \\
2 & $2.5 \times 10^{17}$ & $4 \times 10^{17}$ \\
3 & $9 \times 10^{17}$ & $4 \times 10^{17}$ \\
\hline
\end{tabular}

\section{Acknowledgments.}

The authors wish to express their thanks to Profs. Shoichi Ono and Kuniyoshi Yokoo for their advice and encouragement in executing this study. The CVD reactor was provided by Kokusai Electric Co. Ltd. This study was carried out in the Superclean Room of the Laboratory for Electronic Intelligent Systems, Research Institute of Electrical Communication, Tohoku University and was partially supported by Grant-in-Aid for Scientific Research from the Ministry of Education, Science, and Culture of Japan.

\section{References.}

[1] Patton G.L., Comfort J.H., Meyerson B.S., Crabbé E.F., Scilla G.J., Frésart E.D., Stork J.M.C., Sun J.Y.C., Harame D.L. and Burghartz J.N., IEEE Electron Device Lett. EDL-11 (1990) 171. 
[2] Sturm J.C., Prinz E.J. and Magec C.W., IEEE Electron Device Lett. EDL-13 (1992) 56.

[3] Kasper E., Kibbcl H., Herzog H.J. and Gruhle A., "Growth of $100 \mathrm{GHz} \mathrm{SiGe-HBT} \mathrm{Structures",} \mathrm{Ext.}$ Abstr. 1993 Int. Conf. Solid State Devices and Materials, Makuhari (Business Center for Academic Societies Japan, Tokyo, 1993) pp.419-421.

[4] Meyerson B.S., Appl. Phys. Lett. 48 (1986) 797-799.

[5] Meyerson B.S., Uram K.C. and LeGoues F.K., Appl. Phys. Lett. 53 (1988) 2555-2557.

[6] Murota J., Nakamura N., Kato M., Mikoshiba N. and Ohmi T., Appl. Phys. Lett. 54 (1989) 1007-1009.

[7] Murota J., Kato M., Kircher R. and Ono S., J. Phys. IV France 1 (1991) C1-795-C1-802.

[8] Tsai C., Jang S.-M., Tsai J. and Reif R., J. Appl. Phys. 69 (1991) 8158-8163.

[9] Racanelli M. and Greve D.W., J. Vac. Soc. Technol. B9 (1991) 2017-2021.

[10] Kuhne H., Appl. Phys. Lett. 62 (1993) 1967-1969.

[11] Jang S.-M., Liao K. and Reif R., Appl. Phys. Lett. 63 (1993) 1675-1677.

[12] Bean J.C., Feldman L.C., Fiory A.T., Nakahara S. and Robinson I.K., J. Vac. Sci. Technol. A2 (1984) 436-440.

[13] Schütz R., Murota J., Maeda T., Kircher R., Yokoo K. and Ono S., Appl. Phys. Lett. 61 (1992) 2674-2676.

[14] Murota J., Maeda T, Goto K., Sakamoto K., Aizawa K., Ushioda S. and Ono S., J. Phys. IV France 3 (1993) C3-403-C3-410.

[15] Murota J. and Ono S., Jpn. J. Appl. Phys. Pt. 1, 33 (1994) 2290-2299.

[16] Comfort J.H. and Reif R., J. Electrochem. Soc. 136 (1989) 2386-2398.

[17] Claassen W.A.P. and Bloem J., J. Electrochem. Soc. 127 (1980) 194-202.

[18] Claassen W.A.P., Bloem J., Valkenburg W.G.J.N. and van den Brekel C.H.J., J. Cryst. Growth 57 (1982) 259-266.

[19] Liehr M., Greenlief C.M., Kasi S.R. and Offenberg M., Appl. Phys. Lett. 56 (1990) 629-631.

[20] Gates S.M. and Kurkarni S.K., Appl. Phys. Lett. 58 (1991) 2963-2965.

[21] Liehr M., Greenlief C.M., Offenberg M. and Kasi S.R., J. Vac. Sci. Technol. A8 (1990) 2960-2964.

[22] Greenlief G.M., Wankum P.C., Klug D.-A. and Kecling L.A., J. Vac. Sci. Technol. A10 (1992) 2465-2469.

[23] Murota J., Honma F., Yoshida T., Goto K., Maeda.T, Aizawa K. and Sawada Y., I. Phys. IV France 3 (1993) C3-427-C3-432.

[24] Fistul' V.I., Heavily doped semiconductors (Plenum Press, New York, 1963) pp.252-255.

[25] Bauer S.H., J. Am. Chem. Soc. 78 (1956) 5775-5782. 